\title{
MINERAL COMPOSITION OF ARBOREAL AND BUSH SPECIES OCCURRING IN PASTURES, IN PERNAMBUCO-BRAZIL
}

\author{
COMPOSIÇÃO MINERAL DE ESPÉCIES ARBÓREAS E ARBUSTIVAS EM PASTAGENS, \\ PERNAMBUCO-BRASIL
}

\author{
Almeida, A.C.S. de ${ }^{1 \mathrm{~A}}$, Ferreira, R.L.C. ${ }^{2 \mathrm{~A}}$, Santos, M.V.F. dos ${ }^{2 \mathrm{~B}}$, Lira, M. de A. ${ }^{1 \mathrm{~B}}$, \\ Silva, J.A.A. da $^{2 C}$, Lima, S.B.P. de ${ }^{2 D}$, Cunha, M.V. da ${ }^{3}$ and Sampaio, G.H. ${ }^{2}$

\begin{abstract}
${ }^{1}$ Instituto Agronômico de Pernambuco. IPA. Recife. Pernambuco. Brazil. ${ }^{A}$ carmemsilalmeida@hotmail.com; Bmariolira@terra.com.br

²Universidade Federal Rural de Pernambuco. Arinaldo@dcfl.ufrpe.br; ${ }^{B}$ mercia@dz.ufrpe.br; Cjaaleixo@uol.com.br; Dsteliozoot@yahoo.com.br

3UFRPE. Recife-PE. Brazil.marciovc@msn.com
\end{abstract}

\section{AdDitiONAL KEYWORDS}

Native species. Cultivated species. Dry zone. Humid zone.

\section{SUMMARY}

The aim of the present study was to evaluate, during the dry and wet seasons the mineral composition of tree and bush species occurring in pasture areas near the cities of Itambé, Caruaru and Serra Talhada in the humid, intermediate, and dry climatic zones of the state of Pernambuco (Brazil). Leaves and branches up to $5.0 \mathrm{~mm}$ in diameter were collected for the determination of $\mathrm{N}$, $\mathrm{P}, \mathrm{Mg}$ and $\mathrm{K}$ concentrations. Five, 8, and 14 tree and bush species occurred in the pastures of Itambé, Caruaru and Serra Talhada respectively. In Itambé, $\mathrm{N}$ content was influenced by species, while $\mathrm{P}$ and $\mathrm{K}$ contents were affected by species and season. In Caruaru, N, P and K contents were not influenced by season and in Serra Talhada, only $\mathrm{P}$ and $\mathrm{K}$ contents were influenced by species and season. Chemical composition was generally more adequate in the rainy season.

\section{RESUMO}

O objetivo desse trabalho foi avaliar nos períodos seco e chuvoso de cada região a composição mineral de espécies arbóreas e arbustivas ocorrentes em áreas de pastagem dos Municípios de Itambé, Caruaru e Serra Talhada,

\section{PalaVRas CHAVE ADICIONAIS}

Agreste. Espécies nativas. Espécies cultivadas. Sertão. Zona da Mata.

nas zonas fisiográficas Mata, Agreste e Sertão de Pernambuco. Foram coletadas folhas e galhos com até $5,0 \mathrm{~mm}$ de diâmetro, para a determinação dos teores de N, P, Mg e K. Foram encontradas, respectivamente 5, 8 e 14 espécies arbustivas arbóreas nas pastagens estudadas de Itambé, Caruaru e Serra Talhada. Para Itambé, o teor de N variou conforme a espécie, enquanto que o $\mathrm{P}$ e K variaram conforme a espécie e época do ano. As espécies encontradas em Caruaru, não sofreram influência da época de coleta para N, P e Mg. Em Serra Talhada apenas $\mathrm{P}$ e K sofreram interação época do e ano e espécie. As espécies analisadas apresentaram em geral composições químicas mais satisfatórias no período chuvoso.

\section{INTRODUCTION}

Pasture livestock farming systems consist of a natural combination or a deliberate association of one or more ligneous (bush and arboreal) components within a pasture of native or cultivated grass and herbaceous leguminous species and their use with ruminants and herbivores (Ribaski and Montoya, 2001). The chemical 
composition of species with a ligneous component must be assessed in order to indicate such species as alternatives for pasture livestock farming systems, especially during the dry season, when there is less availability of the herbaceous components in the pasture (Reis et al., 2006). According to Souza et al. (2006), scarce natural resources in semi-arid regions of Brazil, along with periodic droughts and the high demography of the region, force the northeastern region of the country to periodically turn to native and exotic plants that are able to contribute towards subsistence of livestock farming.

According to Carvalho et al. (2001) and Febles et al. (2001), the following are the main characteristics that indicate an arboreal/ bush species as potential fodder for composing a pasture livestock farming system: high germination; ease in establishment; high capacity for re-budding; capability to provide nitrogen and other nutrients to the pasture; adaptation to the environment; tolerance to drought, frost or inundation of the soil; capability to provide palatable fodder; tolerance to pests and diseases; absence of toxic effects on animals; capability to provide shade and shelter; high fodder yield potential; deep roots; efficiency in the use of light; and compatibility with the herbaceous components of the system.

The qualitative assessment of the nutrients in the vegetal component of an agro-forestry system is fundamental to the selection of species with fodder potential that are able to provide a balanced diet rich in protein, energy and minerals. Qualitative assessments also help identify vegetal matter that is toxic to plant hat are toxic for the animals (Franke et al., 2001). Imbalance in an animal diet, particularly minerals, may result in serious nutritional disorders, with a negative impact on the productive and reproductive performance of the animals (Leonel et al., 2006).

The aim of the present study was to assess the mineral composition of arboreal and bush shrubby species occurring in pastures located in Itambé, Caruaru and Serra Talhada in order to obtain information that may contribute toward the diagnosis and planning of pasture livestock farming systems in the state of Pernambuco (Brazil).

\section{MATERIALSAND METHODS}

The study was carried out in pasture native and cultivated areas of the experimental fields of the Pernambuco Livestock Research Institute (IPA, Instituto Agrônomico de Pernambuco) in the counties of Itambé, Caruaru and Serra Talhada in the state of Pernambuco (northeastern Brazil).

Itambé is located in the humid, coastal zone, $96 \mathrm{~km}$ fromRecife (state capital). The climate is warm, rainy and humid, with a dry summer, a mean annual temperature of $24^{\circ} \mathrm{C}$ and mean annual rainfall of $1200 \mathrm{~mm}$. The vegetation is classified as deciduous and sub-deciduous forest (IPA, 1994). The soil is typified as Red-Yellow Argisoil, RedYellow Latosoil and Vertsoil (Embrapa, 1999).

Caruaru is located in the intermediate climatic zone in the interior of the state, $135 \mathrm{~km}$ from Recife. The climate is semi-arid, with a mean annual temperature ranging from $16.7^{\circ}$ to $33.5^{\circ} \mathrm{C}$ and mean annual precipitation rainfall of $600 \mathrm{~mm}$. The predominant vegetation is Hypoxerophile caatinga (IPA, 1994). The soil is typified as RedYellow Latosoil, Red-Yellow Argisoil and Neosoil (Embrapa, 1999).

Serra Talhada is located in the semi-arid region of the deep interior of the state, $418 \mathrm{~km}$ from Recife. The climate is semi-arid, very warm, with a mean annual temperature of $25.9^{\circ} \mathrm{C}$ and mean annual precipitation rainfall of $887.9 \mathrm{~mm}$. The predominant vegetation is Hypoxerophile Caatinga (IPA, 1994). The soil is typified as Red-Yellow Argisoil, Red-Yellow Latosoil, Luvisoil and Neosoil (Embrapa, 1999). 


\section{COMPOSITION OF ARBOREAL AND BUSH SHRUBBY PASTURES SPECIES}

Samples for chemical analysis were collected during the dry and humid seasons. Leaves and branches up to $5.0 \mathrm{~mm}$ in diameter were collected, dried and ground together for the determination of $\mathrm{N}, \mathrm{P}, \mathrm{Mg}$ and $\mathrm{K}$. Analyses were carried out at the vegetal chemistry Laboratory of the Universidade Federal Rural de Pernambuco (UFRPE) following the methodology described by
Bezerra Neto and Barreto (2004). Simultaneously, botanical material was collected for the identification of the arboreal and bush shrubby species in the pasture areas. Specimens were stored at the Sergio Tavares Herbarium of the Forets Science Department (UFRPE). The Cronquist classification system (1981) was used for the separation of the species into families.

Table I. Common and scientific names, family and main uses of evaluated species, according locations locale. (Nome vulgar, científico, família e uso das espécies avaliadas, conforme o local).

\begin{tabular}{|c|c|c|c|}
\hline Local common name & Scientific name & Family & $r$ uses \\
\hline \multicolumn{4}{|l|}{ Itambé } \\
\hline Bordão-de-velho & Chomelia sp & Rubiaceae & \\
\hline Caubin & Casearia sylvestris Sw. & Flacourtiaceae & $\mathrm{F}$ \\
\hline Espinho-de-judeu & Machaerium cultratum Pittier & Fabaceae & \\
\hline Sabiá & Mimosa caesalpiniiaefolia Benth & Mimosaceae & $\mathrm{F}, \mathrm{CC}$ \\
\hline Leucena & Leucaena leucocephala (Lam.) de Wit & Mimosaceae & $\mathrm{F}$ \\
\hline \multicolumn{4}{|l|}{ Caruaru } \\
\hline Algaroba & Prosopis juliflora (Sw.) DC & Mimosaceae & $\mathrm{F}$ \\
\hline Canafístuola & Senna spectabilis (DC.) H.S. Irwin e Barneby & Fabaceae & $\mathrm{MI}$ \\
\hline Catingueira & Caesalpinia pyramidalis Tul. & Caesalpinaceae & $\mathrm{F}, \mathrm{CC}$ \\
\hline Chumbinho & Oxalis insipida St. Hil. & Oxalidaceae & \\
\hline Jurema branca & Piptadenia stipulacea (Benth.) Ducke & Mimosaceae & $\mathrm{F}, \mathrm{CC}$ \\
\hline Jurema preta & Mimosa arenosa Willd & Mimosacea & $\mathrm{F}, \mathrm{CC}$ \\
\hline Marmeleiro & Croton rhamnifolius Humb. Bonpl. E. Kunth. & Euphorbiaceae & $\mathrm{F}, \mathrm{CC}$ \\
\hline Pitombeira & Platymiscium floribundum Vogel & Fabaceae & \\
\hline \multicolumn{4}{|l|}{ Serra Talhada } \\
\hline Angico-de-caroço & Anadenanthera colubrina (Vell.) Brenan var. cebil & Mimosaceae & $\mathrm{F}, \mathrm{CC}$ \\
\hline Aroeira & Myracrodruon urundeuva Allemão & Anacardiaceae & $\mathrm{CC}, \mathrm{Ml}$ \\
\hline Baraúna & Schinopsis brasiliensis Engl. & Anacardiaceae & $\mathrm{F}, \mathrm{CC}$ \\
\hline Catingueira & Caesalpinia cf. bracteosa Tul & Caesalpiniaceae & \\
\hline Imburana & Amburana cearensis (Allemão) A.C.Smith & Anacardiaceae & $\mathrm{CC}$ \\
\hline Joazeiro & Ziziphus joazeiro Mart. & Rhamaceae & \\
\hline Jurema-preta & Mimosa tenuiflora (Willd.) Poir. & Mimosaceae & \\
\hline Marmeleiro & Croton sp & Euphorbiaceae & \\
\hline Mororó & Bauhnia cf. subclavata Benth & Fabaceae & $\mathrm{CC}$ \\
\hline Moleque-duro & Cordia leucocephala Moric & Boraginaceae & $\mathrm{CC}$ \\
\hline Pau-de-leite & Euphorbia sp & Euphorbiaceae & \\
\hline Pereiro & Aspidosperma pyrifolium Mart. & Apocynaceae & \\
\hline Quixabeira & Sideroxylum obtusifolium (Roem. e Schult) T.D.Penn & Sapotaceae & MI \\
\hline Umbuzeiro & Spondias tuberosa Arr. Cam. & Anacardiaceae & MI \\
\hline
\end{tabular}

F: For firewood and coal; CC: For civil construction (rafters, stakes, stanchions, boards and rods); MI: For medicinal and industrial uses (use of tannin for production of leather, resins and adhesives). 
ALMEIDA, FERREIARA, SANTOS, LIRA, SILVA, LIMA, CUNHAAND SAMPAIO

Table II. $N, P, M g$ abd $K$ contents mean \pm SD by species, according to season of the year, Itambé-PE. (Teores media $\pm \mathrm{DP}$ de $\mathrm{N}, \mathrm{P}, \mathrm{Mg}$ e K por espécie, conforme a época, Itambé-PE).

\begin{tabular}{lcccc}
\hline \multirow{2}{*}{ Species } & \multicolumn{2}{c}{ Nitrogen (\%) } & \multicolumn{2}{c}{ Phosphorus (\%) } \\
& Dry season & Rainy season & Dry season & Rainy season \\
\hline Bordão-de-velho & $1.38^{\mathrm{aC}} \pm 0.07$ & $1.7^{\mathrm{aD}} \pm 0.16$ & $0.92^{\mathrm{aA}} \pm 0.13$ & $0.84^{\mathrm{aC}} \pm 0.23$ \\
Caubin & $2.44^{\mathrm{a}} \pm 0.11$ & $2.25^{\mathrm{a}} \pm 0.15$ & $0.94^{\mathrm{aA}} \pm 0.15$ & $1.04^{\mathrm{a}} \pm 0.19$ \\
Espinho-de-judeu & $2.7^{\mathrm{ab}} \pm 0.04$ & $2.61^{\mathrm{a}} \pm 0.09$ & $1.16^{\mathrm{aA}} \pm 0.27$ & $0.72^{\mathrm{aC}} \pm 0.19$ \\
Sabiá & $2.80^{\mathrm{a}} \pm 0.12$ & $2.13^{\mathrm{b}} \pm 0.18$ & $1.02^{\mathrm{b}} \pm 0.32$ & $1.83^{\mathrm{a}} \pm 0.28$ \\
Leucena & $4.14^{\mathrm{aA}} \pm 0.10$ & $4.15^{\mathrm{aA}} \pm 0.20$ & $1.34^{\mathrm{bA}} \pm 0.40$ & $2.51^{\mathrm{aA}} \pm 0.20$ \\
Mean & $2.60 \pm 0.13$ & $2.48 \pm 0.12$ & $1.06 \pm 0.11$ & $1.25 \pm 0.13$ \\
\hline Species & \multicolumn{2}{c}{ Magnesium (\%) } & \multicolumn{2}{c}{ Potassium $(\%)$} \\
& Dry season & Rainy season & Dry season & Rainy season \\
\hline Bordão-de-velho & $0.12 \pm 0.01$ & $0.09 \pm 0.03$ & $0.94^{\mathrm{aB}} \pm 0.11$ & $0.42^{\mathrm{b}} \pm 0.03$ \\
Caubin & $0.08 \pm 0.02$ & $0.06 \pm 0.01$ & $1.16^{\mathrm{aA}} \pm 0.08$ & $0.55^{\mathrm{b} \mathrm{B}} \pm 0.15$ \\
Espinho-de-judeu & $0.09 \pm 0.02$ & $0.06 \pm 0.01$ & $0.82^{\mathrm{B}} \pm 0.07$ & $0.70^{\mathrm{aA}} \pm 0.12$ \\
Sabiá & $0.09 \pm 0.02$ & $0.09 \pm 0.01$ & $0.97^{\mathrm{B}} \pm 0.11$ & $0.42^{\mathrm{B}} \pm 0.13$ \\
Leucena & $0.08 \pm 0.02$ & $0.08 \pm 0.03$ & $0.92 \mathrm{~B} \pm 0.09$ & $0.46^{\mathrm{B}} \pm 0.20$ \\
Mean & $0.09 \pm 0.01$ & $0.07 \pm 0.01$ & $0.98 \pm 0.04$ & $0.52 \pm 0.06$ \\
\hline
\end{tabular}

Means followed by the different small letter in the same species differ according to $F$ test $(p<0.05)$; Means followed by the different capital letter in the same period differ according to Scott-Knott test $(p<0.05)$.

In Itambé, the dry season samplings were carried out in December 2002, November and December 2003, whereas the rainy season collections were carried out in February, July and September 2003. In Caruaru, the dry season samplings were carried out in December 2002, January, November and December 2003, with precipitation rainfall of $2.7 \mathrm{~mm}, 8.3 \mathrm{~mm}, 5.5 \mathrm{~mm}$ and $8.3 \mathrm{~mm}$, respectively; the rainy season collections samplings were carried out in March, April and July 2003, with precipitation rainfall of $62.2 \mathrm{~mm}, 47.1 \mathrm{~mm}$ and 45.1 $\mathrm{mm}$, respectively. In Serra Talhada, the dry season collections were carried out in August and October 2003, with precipitation rainfall of $0.3 \mathrm{~mm}$ and $2.0 \mathrm{~mm}$, respectively; the rainy season samplings were carried out in February and March 2003, with precipitation rainfall of $122.7 \mathrm{~mm}$ and $119.4 \mathrm{~mm}$, respectively (Agritempo, 2007).

The species collected in each location were those most frequent in the area. For analysis of variance, an entirely randomized experimental design in a factorial arrangement was employed, with four replicates. The experimental treatments were the combination of species and seasons (dry and rainy). The means of the variables analyzed were compared using the $\mathrm{F}$ test in the comparison between seasons and the ScottKnott test in the comparison between species. The level of significance was set at $5 \%$. Statistical analyses were performed on the SAEG Statistical and Genetic Analysis System (SAEG, 2000).

\section{RESULTS AND DISCUSSION}

Table I displays a list of the species collected for chemical evaluation; among the study areas, the city of Serra Talhada had the greatest number of species (14), followed by Caruaru, (8) and Itambé (only 5 species recorded). Among the species 


\section{COMPOSITION OF ARBOREAL AND BUSH SHRUBBY PASTURES SPECIES}

collected, there was a predominance of native species and legume families.

Carvalho et al. (2001), Gonçalves and Lelis (2001) and Queiroz et al. (2002) discuss the multiple uses of the different species evaluated in the 4 locations. Besides their importance as fodder, there are other uses that these species may have (table I).

Among the species collected in the Itambé region, leucena (white leadtree) had the greatest (table II) and bordão-de-velho had the lowest $\mathrm{N}$ content, regardless of season. The sampling period influenced the N concentration in the species sabiá, which was higher in the dry season. The $\mathrm{N}$ content for sabiá is similar to that described by
Vieira etal. (2005) and Moura et al. (2006) in the same area. The $\mathrm{N}$ concentration in leucena is similar to that described by Oliveira (2000) in Petrolina (PE, Brazil). For espinheiro (Machaerium aculeatum), which was also found in the Itambé pastures, Ferreira et al. (2007) and Silva et al. (2007) respectively estimated 2.15 and $2.45 \% \mathrm{~N}$ for the average of the seasons (dry and rainy), which are similar to the reported in the present study.

A significant interaction $(\mathrm{p}<0.05)$ occurred between species and seasons, with regard to $\mathrm{P}$ concentration in Itambé (table II). The mean average $\mathrm{P}$ concentration in the species was higher in the rainy

Table III. N, $P, M g$ and $K$ contents mean $\pm S D$ by species, according to season of the year, Caruaru-PE. (Teores media \pm DP N, P, Mg e K por espécie, conforme a época, Caruaru-PE).

\begin{tabular}{|c|c|c|c|c|}
\hline \multirow[t]{2}{*}{ Species } & \multicolumn{2}{|c|}{ Nitrogen(\%) } & \multicolumn{2}{|c|}{ Phosphorus(\%) } \\
\hline & Dry season & Rainy season & Dry season & Rainy season \\
\hline Algaroba & $2.73 \pm 0.17$ & $2.33 \pm 0.07$ & $0.87 \pm 0.26$ & $0.52 \pm 0.11$ \\
\hline Canafístula & $2.81 \pm 0.14$ & $2.95 \pm 0.12$ & $0.96 \pm 0.18$ & $0.81 \pm 0.16$ \\
\hline Catingueira & $1.91 \pm 0.09$ & $1.99 \pm 0.07$ & $0.93 \pm 0.21$ & $0.64 \pm 0.12$ \\
\hline Chumbinho & $1.49 \pm 0.07$ & $1.95 \pm 0.08$ & $0.57 \pm 0.27$ & $0.48 \pm 0.15$ \\
\hline Jurema-branca & $2.34 \pm 0.14$ & $2.26 \pm 0.09$ & $0.52 \pm 0.14$ & $0.68 \pm 0.14$ \\
\hline Jurema-preta & $2.37 \pm 0.16$ & $2.31 \pm 0.22$ & $0.90 \pm 0.23$ & $0.79 \pm 0.23$ \\
\hline Marmeleiro & $1.76 \pm 0.08$ & $1.92 \pm 0.08$ & $1.05 \pm 0.23$ & $0.76 \pm 0.19$ \\
\hline Pitombeira & $2.28 \pm 0.13$ & $2.13 \pm 0.09$ & $0.89 \pm 0.26$ & $0.55 \pm 0.12$ \\
\hline Mean & $2.28 \pm 0.07$ & $2.23 \pm 0.05$ & $0.86 \pm 0.08$ & $0.65 \pm 0.05$ \\
\hline \multirow[t]{2}{*}{ Species } & \multicolumn{2}{|c|}{ Magnesium(\%) } & \multicolumn{2}{|c|}{ Potassium(\%) } \\
\hline & Dry season & Rainy season & Dry season & Rainy season \\
\hline Algaroba & $0.13^{\mathrm{ab}} \pm 0.03$ & $0.15^{\mathrm{ab}} \pm 0.03$ & $2.38 \pm 0.84$ & $1.25 \pm 0.39$ \\
\hline Canafístula & $0.16^{a} \pm 0.02$ & $0.17^{a} \pm 0.03$ & $2.60 \pm 0.59$ & $1.46 \pm 0.46$ \\
\hline Catingueira & $0.11^{b} \pm 0.02$ & $0.14^{\mathrm{ab}} \pm 0.03$ & $3.29 \pm 0.57$ & $1.87 \pm 0.53$ \\
\hline Chumbinho & $0.05^{c} \pm 0.03$ & $0.05^{c} \pm 0.02$ & $1.65 \pm 0.86$ & $0.49 \pm 0.32$ \\
\hline Jurema-branca & $0.12^{\mathrm{ab}} \pm 0.03$ & $0.15^{\mathrm{a}} \pm 0.03$ & $1.72 \pm 0.57$ & $1.84 \pm 0.50$ \\
\hline Jurema-preta & $0.12^{\mathrm{ab}} \pm 0.03$ & $0.12^{\mathrm{ab}} \pm 0.04$ & $2.68 \pm 0.70$ & $1.73 \pm 0.65$ \\
\hline Marmeleiro & $0.09^{b c} \pm 0.02$ & $0.11^{b} \pm 0.02$ & $2.33 \pm 0.70$ & $1.58 \pm 0.47$ \\
\hline Pitombeira & $0.12^{\mathrm{ab}} \pm 0.02$ & $0.08^{\mathrm{bc}} \pm 0.02$ & $1.34 \pm 0.56$ & $1.21 \pm 0.40$ \\
\hline Mean & $0.12 \pm 0.01$ & $0.12 \pm 0.01$ & $2.34^{a} \pm 0.23$ & $1.42^{\mathrm{b}} \pm 0.16$ \\
\hline
\end{tabular}

Means followed by the different small letter in the same species differ according to $F$ test $(p<0.05)$; Means followed by the different capital letter in the same period differ according to Scott-Knott test $(p<0.05)$. 
season and leucena (white leadtree) had the highest $\mathrm{P}$ content in this season.

A significant interaction $(\mathrm{p}<0.05)$ was found for $\mathrm{K}$ content with higher values in the dry season (table II). Caubin had the highest $\mathrm{K}$ content in the dry season, whereas espinho-de-judeu had the highest K content in the rainy season. $\mathrm{Mg}$ variations were non-significant (table II).

$\mathrm{N}$ and $\mathrm{P}$ concentrations did not differ significantly $(\mathrm{p}>0.05)$ between species or seasons in Caruaru (table III). The species

Table IV. N, P, Mg and K contents mean \pm SD by species, according to season of the year, Serra Talhada-PE. (Teores media \pm DP de N, P, Mg e K por espécie, conforme a época, Serra Talhada-PE).

\begin{tabular}{|c|c|c|c|c|}
\hline \multirow[t]{2}{*}{ Species } & \multicolumn{2}{|c|}{ Nitrogen(\%) } & \multicolumn{2}{|c|}{ Phosphorus(\%) } \\
\hline & Dry season & Rainy season & Dry season & Rainy season \\
\hline Angico-de-caroço & $1.70^{\mathrm{bA}} \pm 0.05$ & $2.51^{\mathrm{aA}} \pm 0.12$ & $2.65 \pm 0.99$ & $0.58 \pm 0.01$ \\
\hline Aroeira & $1.08^{\mathrm{bc}} \pm 0.18$ & $1.57^{\mathrm{ac}} \pm 0.15$ & $0.24 \pm 0.00$ & $0.60 \pm 0.03$ \\
\hline Baraúna & $1.49^{\mathrm{aB}} \pm 0.11$ & $1.83^{\mathrm{aB}} \pm 0.17$ & $1.07 \pm 0.37$ & $0.60 \pm 0.01$ \\
\hline Catingueira & $1.16^{\mathrm{bc}} \pm 0.08$ & $2.23^{\mathrm{aA}} \pm 0.10$ & $1.41 \pm 0.36$ & $0.59 \pm 0.01$ \\
\hline Imburana & $1.44^{\mathrm{aB}} \pm 0.25$ & $1.52^{\mathrm{ac}} \pm 0.09$ & $0.86 \pm 0.86$ & $0.62 \pm 0.01$ \\
\hline Joazeiro & $1.82^{\mathrm{aA}} \pm 0.06$ & $2.02^{\mathrm{aB}} \pm 0.09$ & $1.40 \pm 0.36$ & $0.65 \pm 0.04$ \\
\hline Jurema-preta & $1.61^{\mathrm{bB}} \pm 0.09$ & $2.08^{\mathrm{aB}} \pm 0.06$ & $1.45 \pm 0.40$ & $0.58 \pm 0.01$ \\
\hline Marmeleiro & $1.19^{\mathrm{bc}} \pm 0.10$ & $1.92^{\mathrm{aB}} \pm 0.12$ & $1.02 \pm 0.53$ & $0.48 \pm 0.10$ \\
\hline Moleque-duro & $1.81^{\mathrm{aA}} \pm 0.08$ & $1.86^{\mathrm{aB}} \pm 0.20$ & $0.60 \pm 0.60$ & $0.60 \pm 0.02$ \\
\hline Mororó & $1.15^{\mathrm{bc}} \pm 0.06$ & $1.94^{\mathrm{aB}} \pm 0.15$ & $1.24 \pm 1.24$ & $0.61 \pm 0.01$ \\
\hline Pau- de-leite & $1.00^{\mathrm{bC}} \pm 0.07$ & $1.55^{\mathrm{aC}} \pm 0.06$ & $1.73 \pm 0.33$ & $0.60 \pm 0.01$ \\
\hline Pereiro & $1.22^{\mathrm{aC}} \pm 0.04$ & $1.38^{\mathrm{aC}} \pm 0.04$ & $1.32 \pm 0.54$ & $0.58 \pm 0.01$ \\
\hline Quixabeira & $1.81^{\mathrm{aA}} \pm 0.10$ & $1.93^{\mathrm{aB}} \pm 0.24$ & $1.04 \pm 0.40$ & $0.62 \pm 0.01$ \\
\hline Umbuzeiro & $0.96^{\mathrm{bc}} \pm 0.03$ & $1.65^{\mathrm{aC}} \pm 0.07$ & $0.72 \pm 0.46$ & $0.64 \pm 0.00$ \\
\hline Mean & $1.39 \pm 0.05$ & $1.86 \pm 0.05$ & $1.29^{a} \pm 0.16$ & $0.59^{b} \pm 0.01$ \\
\hline \multirow[t]{2}{*}{ Species } & \multicolumn{2}{|c|}{ Magnesium(\%) } & \multicolumn{2}{|c|}{ Potassium(\%) } \\
\hline & Dry season & Rainy season & Dry season & Rainy season \\
\hline Angico-de-caroço & $0.02 \pm 0.01$ & $0.07 \pm 0.02$ & $1.10 \pm 0.54$ & $0.63 \pm 0.12$ \\
\hline Aroeira & $0.05 \pm 0.02$ & $0.09 \pm 0.01$ & $0.63 \pm 0.02$ & $0.56 \pm 0.07$ \\
\hline Baraúna & $0.04 \pm 0.02$ & $0.26 \pm 0.07$ & $1.40 \pm 0.74$ & $0.84 \pm 0.21$ \\
\hline Catingueira & $0.05 \pm 0.02$ & $0.11 \pm 0.05$ & $1.97 \pm 0.83$ & $0.71 \pm 0.25$ \\
\hline Imburana & $0.02 \pm 0.01$ & $0.10 \pm 0.00$ & $0.38 \pm 0.33$ & $0.85 \pm 0.25$ \\
\hline Joazeiro & $0.08 \pm 0.02$ & $0.23 \pm 0.06$ & $2.63 \pm 0.61$ & $0.84 \pm 0.07$ \\
\hline Jurema-preta & $0.06 \pm 0.02$ & $0.16 \pm 0.02$ & $1.03 \pm 0.42$ & $0.77 \pm 0.10$ \\
\hline Marmeleiro & $0.01 \pm 0.01$ & $0.07 \pm 0.03$ & $0.23 \pm 0.15$ & $0.79 \pm 0.11$ \\
\hline Moleque-duro & $0.07 \pm 0.07$ & $0.07 \pm 0.04$ & $0.11 \pm 0.11$ & $0.72 \pm 0.19$ \\
\hline Mororó & $0.07 \pm 0.07$ & $0.10 \pm 0.06$ & $1.10 \pm 0.96$ & $0.58 \pm 0.09$ \\
\hline Pau-de-leite & $0.09 \pm 0.02$ & $0.13 \pm 0.04$ & $1.46 \pm 0.55$ & $0.74 \pm 0.13$ \\
\hline Pereiro & $0.06 \pm 0.03$ & $0.12 \pm 0.04$ & $1.20 \pm 0.73$ & $0.87 \pm 0.10$ \\
\hline Quixabeira & $0.09 \pm 0.03$ & $0.21 \pm 0.12$ & $2.16 \pm 0.70$ & $0.83 \pm 0.12$ \\
\hline Umbuzeiro & $0.05 \pm 0.02$ & $0.13 \pm 0.02$ & $2.42 \pm 1.00$ & $1.00 \pm 0.16$ \\
\hline Mean & $0.05^{b} \pm 0.01$ & $0.13^{a} \pm 0.01$ & $1.29^{a} \pm 0.17$ & $0.76^{b} \pm 0.04$ \\
\hline
\end{tabular}

Means followed by the different small letter in the same species differ according to $F$ test $(p<0.05)$; Means followed by the different capital letter in the same period differ according to Scott-Knott test $(p<0.05)$.

Archivos de zootecnia vol. 60, núm. 231, p. 558. 


\section{COMPOSITION OF ARBOREAL AND BUSH SHRUBBY PASTURES SPECIES}

algaroba (mesquite), cana-fístula, catingueira, jurema-branca and jurema-preta had higher $\mathrm{Mg}$ values $(\mathrm{p}<0.05)$ than the chumbinho (table III) and they were not influenced by season. Average $\mathrm{K}$ content was higher in the dry season $(\mathrm{p}<0.05)$.

Regarding the data obtained in Serra Talhada, the species angico-de-caroço, joazeiro, moleque-duro and quixabeira had a higher $\mathrm{N}$ content concentration than other species $(\mathrm{p}<0.05)$ in the dry season, whereas only angico-de-caroço and catingueira do it in the rainy season (table III), thereby showing an interaction between species and season. The $\mathrm{P}$ and $\mathrm{K}$ concentrations were higher $(\mathrm{p}<0.05)$ in the dry season (table III) and $\mathrm{K}$ content concentration was higher in the rainy season.

The mineral content in plants is influenced by characteristics that are inherent to the species and environment. According to Larcher (2000), the proportion of various bioelements may be strongly determined by plant species and family, by organ or by stage of development. In general, N, P and $\mathrm{K}$ content varied in accordance with the species, season and locations, which may be associated to the high mobility of these minerals (Malavolta et al., 1989) as well as the immobility of magnesium in the plant (Epstein, 1974).

Phosphorus is one of the most important elements for cattle, especially cattle kept in pastures. Extensive areas of pastures with phosphorus deficiency occur throughout the world and there is no doubt that this is the most common mineral deficiency among cattle (Tokarnia et al., 2000). According to Moraes (2001), $0.12 \% \mathrm{P}$ in the dry matter of tropical fodder is closer to the needs of

\section{BIBLIOGRAPHY}

Agritempo. Sistema de Monitoramento Agrometeorológico. http://www.agritempo.gov.br/agroclima. (15/12/07).

Araújo, G.G.L, Albuquerque, S.G. e Guimarães Filho, C. 2001. Opções no uso de forrageiras cattle than levels established by the American National Research Council (overestimated at $30 \%$ for the conditions of the country). Thus, the content in most of the species evaluated in the three locations achieved this value.

Knowledge on the mineral composition of fodder in different locations and seasons provides information for the assessment of mineral and nutritional supplements for animal feeding. Furthermore, information on the degree of mineral extraction from different plants is important to the assessment of fertilizer possibilities. The species bordãode-velho collected in Itambé, marmeleiro and chumbinho collected in Caruaru and aroeira, baraúna, catingueira, imburana, jurema preta, mameleiro, moleque-duro, mororó, pau-de-leite, pereiro, quixabeira and umbuzeiro collected in Serra Talhada (tabla IV) exhibited $\mathrm{N}$ content concentration below $1.92 \%$, which Araújo et al. (2001) consider the minimum satisfactory value of crude protein $\mathrm{N}$. It should be stressed that, besides the chemical components of the species occurring in pastures, aspects such as ease of propagation, adaptation to climatic conditions, type of animal and objectives of the animal production system should be considered in the choice of species for use in pasture animal husbandry systems.

Regardless of the locations, the species analyzed exhibited different content concentration of $\mathrm{N}, \mathrm{P}, \mathrm{Mg}$ and $\mathrm{K}$ as a result of variations seasonal. It is noteworthy that the legume species may have an influence on $\mathrm{N}$ concentration. Chemical compositions was generally more satisfactory in the rainy season. arbustivo-arbóreas na alimentação no semiárido do Nordeste. Em: Carvalho, M.M., Alvin, M.J., Carneiro, J.C. (Eds.). Sistemas agroflorestais pecuários: opções de sustentabilidade para áreas tropicais e subtropicais. EMBRAPA 


\section{ALMEIDA, FERREIARA, SANTOS, LIRA, SILVA, LIMA, CUNHAAND SAMPAIO}

Gado de Leite. Juiz de Fora. FAO. Brasília. pp. 111-137.

Bezerra Neto, E. and Barreto, L. P. 2004. Métodos de análises químicas em plantas. UFRPE. Recife. $165 \mathrm{pp}$.

Carvalho, M.V.B.M.A., Ferreira, R.L.C., Dos Santos, M.V.F., Dubeux Júnior, J.C.B., Freitas, A.M.M. e Almeida, O.C. 2001. Caracterização de propriedades rurais e identificação de espécies arbóreas e arbustivas ocorrentes em pastagens do Agreste de Pernambuco. Rev. Cient. Prod. Anim., 3: 38-54.

Cronquist, A. 1981. An integrated system of classification of flowering plant. Columbia University. Press. New York. 1262 pp.

EMBRAPA. Empresa Brasileira de Pesquisa Agropecuária. 1999. Sistema brasileiro de classificação de solos. Embrapa Solos. Brasília. Rio de Janeiro. 412 pp.

IPA. 1994. Empresa Pernambucana de Pesquisa Agropecuária. Banco de dados agro-metereológicos. Recife. 100 pp.

Epstein, E. 1974. Nutrição mineral das plantas; princípios e perspectivas. Livros Técnicos e Científicos. Universidade de São Paulo. 341 pp.

Febles, G., Ruiz, T.E., Alonso, J. e Chongo, B. 2001. Metodologia de avaliação de germoplasmas nativo e exótico para seu emprego em sistemas silvipastoris em Cuba. Em: Carvalho, M.M., Alvin, M.J., Carneiro, J.C. (Eds.). Sistemas agroflorestais pecuários: opções de sustentabilidade para áreas tropicais e subtropicais. Embrapa Gado de Leite. FAO. Juiz de Fora. Brasília. pp. 363-377.

Ferreira, R.L.C., De Oliveira, C.A.M., Da Cunha, M.V., Dos Santos, M.V.F. e Lira. M.A. de. 2007. Variação anual de nutrientes em Machaerium aculeatum Raddi sob pastagem. Caatinga, 20: 15-21.

Franke, I.L., Lunz, A.M.P., Valentim, J.F., do Amaral, E.F. e Miranda, E.M. 2001. Situação atual e potencial dos sistemas silvipastoris no Estado do Acre. Em: Carvalho, M.M., Alvim, M.J., Carneiro, J.C. da. Sistemas agroflorestais pecuários: opções de sustentabilidade para áreas tropicais e subtropicais. Embrapa Gado de Leite. Juiz de Fora. FAO. Brasília. pp. 19-40.

Gonçalves, C.A. and Lelis, R.C.C. 2001. Teores de taninos na casca e na madeira de cinco leguminosas arbóreas. IPA. Floresta Ambient., 8:
167-173.

Larcher, W. 2000. Ecofisiologia vegetal. Rima Artes e Textos. São Carlos-SP: 531 pp.

Leonel, F.P., Pereira, J.C., Vieira, R.A.M., Freitas, J.A., Dutra, A.R., Lima, A.V., Ribeiro, M.D. e Costa, M.G. 2006. Exigências nutricionais em macronutrientes minerais ( $\mathrm{Ca}, \mathrm{P}, \mathrm{Mg}, \mathrm{Na}$ e $\mathrm{K}$ ) para novilhos de diferentes grupos genéticos. Rev. Bras. Zootecn., 35: 584-590.

Malavolta, E.,Vitti, G.C. e Oliveira, S.A. 1989. Avaliação do estado nutricional das plantas: princípios e aplicações. POTAFOS. Piracicaba. $201 \mathrm{pp}$.

Moraes, S.S. 2001. Importância da suplementação mineral para bovinos de corte. CNPGC/ EMBRAPA. MS. Campo Grande. 26 pp.

Moura, O.N., Passos, M.A.A., Ferreira, R.L.C., Molica, S.G., Lira Júnior, M. de A., Lira, M. de A. e Dos Santos, M.V.F. 2006. Distribuição de biomassa e nutrientes na parte aérea de Mimosa caesalpiniaefolia. Benth. Rev. Árvore. 30: 877884.

Oliveira, M.C. 2000. Leucena - suplemento protéico para a pecuária do semi-árido no período seco. EMBRAPA-CPATSA. Petrolina. PE. 14 pp.

Queiroz, C.R.A.A., Moraes, S.A.L. e Nascimento, A. 2002. Caracterização dos taninos da aroeira -preta (Myracrodruon urundeuva). Rev. Árvore, 26: 485-492.

Reis, A.M.S., Araújo, E.L., Ferraz, E.M.N. e Moura, A.N. 2006. Variações interanuais na florística e fitossociologia do componente herbáceo de uma área de caatinga, Pernambuco, Brazil. Acta Bot. Brasílica., 29: 497-508.

Ribaski, J. and Montoya, A.N. 2001. Sistemas silvipastoris desenvolvidos na região sul do Brasil: a experiência da Embrapa Florestas. Em: Carvalho, M.M., Alvin, M.J., Carneiro, J.C. (Eds.). Sistemas agroflorestais pecuários: opções de sustentabilidade para áreas tropicais e subtropicais. Embrapa Gado de Leite. Juiz de Fora. FAO. Brasília.

SAEG-Sistema para análises estatísticas e genéticas. 2000. UFV. Viçosa.

Silva, M.A., Dubeux Junior, J.C.B., De Lira, M.A., Dos Santos, M.V.F., Ferreira, R.L.C. e Santos, G.R.A. 2007. Caracterização de espinheiro (Machaerium, aculeatum Raddi). Itambé. Rev. Bras. Ciênc. Agrár., 2: 98-106.

Souza, E.J.O., Guim, A., Batista, A.M.V., Zumba, 


\section{COMPOSITION OF ARBOREAL AND BUSH SHRUBBY PASTURES SPECIES}

E.R.F., Santos, E.P., Souza, K.S., Santos, G.R.A., Lins, N.B. e Matos, D.S. 2006. Qualidade de silagens de maniçoba (Manihot epruinosa) emurchecida. Arch. Zootec., 55: 351-360.

Tokarnia, C.H., Döbereiner, J. e Peixoto, P.V. 2000.

Deficiências minerais em animais de fazenda, principalmente bovinos em regime de campo.

Pesq. Vet. Bras., 20: 127-138.
Vieira, E.L., Carvalho, F.F.R., Batista, A.M.V. Ferreira, R.L.C., Dos Santos, M.V.F., De Lira, M.A., Da Silva, M.J. e Da Silva, E.M.B. 2005. Composição química de forrageiras e seletividade de bovinos em bosque-desabiá (Mimosa caesalpiniaefolia Benth.) nos períodos chuvoso e seco. Rev. Bras. Zootecn. 34: 1505-1511.

Archivos de zootecnia vol. 60, núm. 231, p. 561. 